\title{
Genesis of hydrous-oxidized parental magmas for intraplate porphyry deposits
}

\author{
R.Z. $\mathrm{HU}^{1,2^{*}}$, X.W. BI ${ }^{1}$, L.L. XU ${ }^{1}$, J.J. ZHU ${ }^{1}$, L.C. PAN ${ }^{1}$, \\ M.L. HUANG ${ }^{1}$
}

${ }^{1}$ State Key Laboratory of Ore Deposit Geochemistry, Institute of Geochemistry, Chinese Academy of Sciences, Guiyang, 550081, China (*huruizhong@vip.gyig.ac.cn)

${ }^{2}$ College of Earth and Planetary Sciences, University of Chinese Academy of Sciences, Beijing 100049, China

Porphyry deposits are significant repositories of copper, gold, and molybdenum in the world. They can not only occur in active continental margins but also in intraplate settings. In both cases however, a hydrous-oxidized felsic parental magma appears to be the prerequisite. Although the origin of such magma in subduction zones is well known, i.e., by flux melting in the overlying mantle wedge, little is known in the intraplate setting. To address this outstanding issue, the deposits from the Eocence-Oligocence intraplate Yulong and Ailaoshan porphyry $\mathrm{Cu}-\mathrm{Au}-\mathrm{Mo}$ belts in the Sanjiang region, SW China were investigated.

Reliable geochronological data for these deposits indicate that they formed between 44 and $32 \mathrm{Ma},>10$ million years after the last oceanic subduction in the adjacent Himalaya region located several hundreds of kilometers away from the belts. The trace element and isotope data support that the parental magmas of the deposits were all derived from a metasomatized lithospheric mantle, mixing with melts derived from the overlying crust. The mantle metasomatism in the Yulong and Ailaoshan regions can be attributed to the known previous subduction that took place in the Permian-Triassic and Neoproterozoic, respectively. Magmatic amphibole compositions indicate that the parental magmas are all relatively oxidized, with estimated $\triangle \mathrm{FMQ}$ values of $\sim 2.1 \pm 0.8$, and have high $\mathrm{H}_{2} \mathrm{O}$ contents $(3.7 \pm 0.5$ wt.\%). These results are further supported by high $\mathrm{Ce}^{4+} / \mathrm{Ce}^{3+}$ ratios (115-789) in magmatic zircons and abundant hydrous silicate minerals such as amphibole and biotite in the host rocks. After taking into account the effects of magma differentiation such as crustal assimilation, fractional crystallization and degassing during magma ascent, we conclude that the parental magmas for these deposits are originally oxidized and $\mathrm{H}_{2} \mathrm{O}$-rich prior to differentiation in the crust. We attribute such characteristics to inheritance from the mantle sources that were oxidized and hydrated by previous slab-derived fluids and subducted sediment-derived melts. 